\title{
DUE PROCESS AND CONFINEMENT FOR MENTAL DISORDER
}

\section{GARY DRAPER*}

\begin{abstract}
One may lose his freedom by being confined to a mental institution. The meaning of "due process of law" is examined with regard to determining whether a person being confined to a mental institution in Alberta receives the benefits of due process of law. The processes by which a criminal is confined are compared with those by which a mentally disordered person is confined. The article concludes that in many instances the mentally disordered are deprived of their freedom without due process of law.
\end{abstract}

\section{INTRODUCTION}

There are two main reasons for which a person may lose his freedom in our society. One reason is his having been found guilty of a criminal offence. The other is his having been found mentally disordered and dangerous to himself or others. A tremendous amount of attention has been paid to the criminal process and protection of the civil liberties of persons accused or convicted of a criminal offence, but until recently little attention has been paid to the other process by which one may lose his or her liberty.

Deprivation of freedom for mental disorder occurs under two processes. If one is accused of a criminal offence and found unfit to stand his trial because of mental disorder or found not guilty of the offence by reason of insanity, he may be committed to an indefinite period of detention under a lieutenantgovernor's warrant. The authority is given to the federal Parliament as part of the criminal law power contained in s. 91(27) of the British North America Act. ${ }^{1}$

The provincial Legislature has authority to enact legislation permitting the involuntary commitment of citizens for mental disorder per se. This jurisdiction is conferred by s. 92(7) (The Establishment, Maintenance, and Management of Hospitals, Asylums, Charities and Eleemosynary Institutions in and for the Province, other than Marine Hospitals) and s. 92(16) (Generally all Matters of a merely local or private Nature in the Province) of the B.N.A. Act.

This article endeavours to examine both of these procedures used to deprive persons of their liberty, comparing them with each other and with the ordinary criminal process. The comparison is in terms of how well the procedures measure up to due process of law. For, as Meredith J.A. has stated: ${ }^{2}$

The effect of the incarceration of a person in a public lunatic asylum in this Province is of so far reaching a character, as to both person and property, that every care should be taken that all the requirements of the law authorizing it are duly observed by everyone bringing it about or concerned in it. ...

\section{DUE PROCESS OF LAW}

\section{A. English Antecedents}

Before examining the commitment procedures in detail it would be advisable to briefly look at the term "due process of law," what it has

\footnotetext{
- Of the graduating class of 1976, Faculty of Law, University of Alberta.

I R.S.C. 1970, Appendix II, No. 5.

2 Re Gibson (1908) 15 O.L.R. 245 (Ont. C.A.) at 248.
} 
traditionally meant, and what it means today.

The term has been traced to the Magna Carta of 1215. Article 39 of the Charter provided:

No free man shall be captured or imprisoned or disseised or outlawed or exiled or in any way destroyed, nor will we go against him or send him, except by the lawful judgment of his peers or by the law of the land.

The phrases "the law of the land" and "due process of law" are generally regarded as being synonymous, the latter phrase first appearing somewhat over a century later. ${ }^{3}$ The scope of the phrase in the Magna Carta, whether or not it was to have substantive content, or was to be understood in a more limited context is still a matter of historical controversy. ${ }^{4}$

The phrase probably reached its greatest effect as an instrument of judicial control over legislative action in England between 1609 and 1616 while Lord Coke was chief justice of the Kings Bench. During that period, Acts of Parliament and the Crown were declared void as infringing the fundamental law of the land as set out in the Magna Carta. However, when Cromwell's attempt at a written constitution for England, the "Agreement of the People," failed to go into effect, the doctrine began to fall out of favour. By 1765 Blackstone could declare in his famous Commentaries that Parliament was supreme and that nothing could fetter its discretion. This English view of due process as being the law as enacted by Parliament, whatever that might be, has survived to the present day.

\section{B. American View}

The term "due process of law" appears in the Fifth and Fourteenth Amendments to the United States Constitution. ${ }^{5}$ The United States Supreme Court has interpreted the phrase in both amendments very widely. They are given a substantive control over federal and state legislation because of their incorporation into the Constitution. Indeed, prior to $1964^{6}$ the Supreme Court interpreted the words in the Fourteenth Amendment to mean those canons of decency and fairness which express the notions of justice of the English speaking peoples. The phrase has been held to include protection against unreasonable searches and seizures, against double jeopardy, and guarantee of a right to counsel, among other things. ${ }^{7}$

\section{Canadian Bill of Rights}

Section 1(a) of the Canadian Bill of Rights ${ }^{8}$ states:

1. It is hereby recognized and declared that in Canada there have existed and shall continue to exist without discrimination by reason of race, national origin, colour, religion or sex, the following human rights and fundamental freedoms, namely,

(a) the right of the individual to life, liberty, security of the person and enjoyment of property, and the right not to be deprived thereof except by due process of law; . . . (emphasis added).

The meaning of the phrase "due process of law" was first examined in 1961

3 28 Edward III, c. 3. "That no man of what estate or condition that he be, shall be put out of land or tenement, nor taken, nor imprisoned, nor disinherited, nor put to death, without being brought in answer by due process of the law."

- See R. L. Mott, Due Process of Law, 1973 (Reprint), c. III for a discussion of the question.

s Amendment V: "No person . . . nor be deprived of life, liberty or property, without due process of law; . . .". Amendment XIV: ". . . nor shall any State deprive any person of life, liberty, or property, without due process of the law;....."

6 Malloy v. Hogan 378 U.S. 46 (1964).

7 See, respectively, Mapp v. Ohio (1961) 367 U.S. 643; Benton v. Maryland (1969) 395 U.S. 784; Gideon v. Wainwright (1963) 372 U.S. 335.

N.S.C. 1970 Appendix III. 
by the Alberta Court of Appeal in $R$. v. Martin. ${ }^{9}$ The court held that due process of law means in accordance with the law of the land as determined by the statutes of Parliament. In Wisconsin v. Armstrong ${ }^{10}$ the Federal Court of Appeal decided that, in extradition proceedings, "due process" does not call for any different or further legal process than that prevailing prior to enactment of the Bill of Rights, in effect the same meaning as in $R$. v. Martin.

The Supreme Court of Canada has considered the meaning of the phrase only once, in Curr v. $R .{ }^{11}$ In his minority concurring judgment Ritchie J. stated that the meaning of the phrase as used in the Bill of Rights was "according to the legal processes recognized by Parliament and the courts of Canada,"12 the traditional English approach.

Laskin J. (as he then was) wrote the majority decision. He clearly states that "due process of law" has a procedural aspect which guarantees that a person is not to be deprived of any of his specified rights without certain procedures being followed: ${ }^{13}$

It is evident from $\mathbf{s}$. 2 of the Canadian Bill of Rights that its specification of particular procedural protections is without limitation of any others that may have a source in 8.1 .

Insofar as 8. 223 and especially s. 223(1) [of the Criminal Code], may be regarded as a procedural aid to the enforcement of the substantive offence created by $\mathrm{s}$. 222, I do not find it obnoxious to s. 1(a) of the Canadian Bill of Rights. I am unable to appreciate what more can be read onto $s$. 1(a) from a procedural standpoint than is already comprehended by 8 . 2(e) (a fair hearing in accordance with the principles of fundamental justice) and by s. 2(f) (a fair and public hearing by an independent and impartial tribunal).

Laskin J. does not explicitly decide whether or not the due process clause can be used in the same manner as the U.S. Fifth Amendment has been utilized to control the substantive content of federal legislation. He implies that it might be so used. However, compelling reasons relating to objective and manageable standards must be advanced before a court will consider holding a federal statute inoperative as offending substantive due process. Therefore, due process in the Bill of Rights can safely be said to require a fair hearing by an impartial tribunal, but its extent beyond that procedural aspect is a matter of conjecture.

Nevertheless, s. 2 of the Canadian Bill of Rights provides something of a guide to the scope of "due process." It says in part:

2. Every law of Canada ... shall be so construed and applied as not to abrogate, abridge or infringe .... any of the rights or freedoms herein recognized and declared, and in particular, no law of Canada shall be construed or applied so as to . . . [followed by seven enumerated protections]. (emphasis added)

It is evident from reading the section that the words "herein recognized and declared" must refer back to the rights and freedoms declared in s. 1. Also, the words "in particular" must mean that the enumerated protections in s. 2 are merely non-exclusive particularizations of the rights set forth in s. 1 . Thus, due process of law might also include a protection against arbitrary detention, the right to counsel and the right to habeas corpus as well as the right to a fair hearing by an impartial tribunal declared by Laskin J. This construction of s. 2 is supported by Martland J., speaking for the Supreme Court of Canada, in Lowry \& Lepper v. R.: ${ }^{14}$

\footnotetext{
(1961) 35 C.R. 276,35 W.W.R. 385,131 C.C.C. 32 (Alta. C.A.).

10 (1973) 10 C.C.C. (2d) 271 (Fed. C.A.).

" (1972] S.C.R. 889, 26 D.L.R. (3d) 603, 7 C.C.C. (2d) 181, 18 C.R.N.S. 281.

12 Id. at D.L.R. 607.

13 Id. at 612.

14 [1974] S.C.R. 195, (1972) 26 D.L.R. (3d) 224, 6 C.C.C. (2d) 531, 19 C.R.N.S. (S.C.C.).
} 
The various paragraphs in $\mathrm{s}$. 2 particularize aspects of those human rights and fundamental freedoms defined in s. 1. Paragraph (a) of 8.1 refers to the right to life, liberty and security of the person, as well as to the enjoyment of property and the right not to be deprived thereof except by due process of law. The right to a fair hearing in accordance with the principles of fundamental justice for the determination of rights and obligations, provided for in s. 2(e), relates back to those rights guaranteed by s. $1 . .^{15}$

Of course, in considering the meaning of due process in the Canadian Bill of Rights it must be remembered that the Supreme Court of Canada has held that the Act is not concerned with human rights and fundamental freedoms in any abstract sense, but rather the rights and freedoms existing in Canada immediately before the statute was enacted.16 Therefore, the judicial interpretations are not statements of "due process" in a general all-inclusive sense, but only within the Bill of Rights.

\section{Alberta Bill of Rights}

The Alberta Bill of Rights ${ }^{17}$ also contains a due process clause in exactly the same form as in the Canadian Bill of Rights, except that the right to life is omitted (presumably because the provincial Legislature has no jurisdiction to enact legislation depriving a person of his life). In view of the virtually identical language in the two Acts and the fact that the preamble to the Alberta Bill of Rights states that it is based on the federal Act, it is submitted that the phrase "due process of law" in the provincial Act should be interpreted in the same manner as in the federal Bill of Rights. This appears to be the most reasonable construction of the Act. As a result of Lowry \& Lepper v. $R$. (which was decided prior to passage of the Alberta Act), it must be assumed that the Alberta Legislature deemed it unnecessary to particularize in s. 2 of the Alberta Bill of Rights the rights and fundamental freedoms declared in s. 1. Thus, the effect of the Alberta Act should be virtually the same as that of the Canadian Bill of Rights.

\section{E. Due Process}

As the preceding discussion has demonstrated, the phrase "due process to law" has many shades of meaning. For the purpose of comparing the various procedures for confinement of the mentally disordered, the words will be considered in their broadest terms. That is, the procedures will be examined to see how "fair" they are to the person being subjected to them, in view of what the law of the English speaking world has generally considered to be fair and just. The issue of what constitutes due process of law, as set out in the Canadian Bill of Rights and the Alberta Bill of Rights, as it applies to the mentally disordered will be discussed in Part V of the article.

\section{CONFINEMENT}

\section{A. Procedure}

\section{Civil Confinement}

The procedure for committing a person involuntarily to a mental institution is set out in the Alberta Mental Health Act. ${ }^{18}$ There are three procedures for conveying a person to a mental hospital: (1) issue of a conveyance and examination certificate, (2) issue of an order for apprehension, and (3) conveyance by a police officer.

\footnotetext{
15 Id., 26 D.L.R. (3d) at 228.9. This construction was affirmed in the minority judgment of Laskin C.J.C. in A.G. Canada v. Canard (1975) 52 D.L.R. (3d) 548 (S.C.C.).

16 Robertson \& Rosetanni v. R. (1964) 41 D.L.R. (2d) 485, 41 C.R. 392, [1941] 1 C.C.C. 1 (S.C.C.).

17 S.A. 1972 , c. 1.

is S.A. 1972 , c. 118 as amended S.A. 1973 , c. 76.
} 
Section 25 of the Mental Health Act describes the issue of a conveyance and examination certificate. Where a physician or a therapist (the qualifications for therapists have not been determined yet and none have yet been appointed) examines a person and is of the opinion that the person is suffering from mental disorder and is in a condition presenting a danger to himself or others, he may issue a conveyance and examination certificate in respect of the person. The certificate is authority for anyone to convey and detain the person named therein to a designated facility (Alberta Hospital, Ponoka, or Alberta Hospital, Edmonton-"Oliver").19 The certificate authorizes examination, observation, treatment, care of, detention and control of the named person at the facility for a period of 24 hours following arrival..$^{20}$

While only a physician may issue a conveyance and examination certificate, anyone may lay an information before a provincial judge that a person is suffering from mental disorder, is in a condition dangerous to himself or others, refuses to be examined and that there is no other way to arrange an examination. The provincial judge may issue to any or all peace officers, an order for apprehension of the person for an examination.21

According to s. 34 of the Act, where a police officer observes a person who appears to be suffering from mental disorder, is in a condition dangerous to himself or others, and is acting disorderly, the police officer may, where satisfied that the person should be examined and that to wait for an order for apprehension from a provincial judge would be dangerous, convey the person to a mental facility for an examination..$^{22}$ The decision in Beatty \& Mackie v. Kozak ${ }^{23}$ (considering an almost identical provision in the Saskatchewan Mental Health Act) clearly indicates that this is not to be utilized as a common vehicle for conveyance to a hospital, but is an emergency provision.

Two admission certificates are necessary to detain a person beyond the 24 hour period authorized by the conveyance and examination certificate. Where two physicians (or a therapist and a physician) are of the opinion that a person is suffering from mental disorder, in a condition presenting a danger to himself or others and unsuitable for committal except as an involuntary patient, after separate examinations, each shall issue an admission certificate. ${ }^{24}$ Two admission certificates authorize detention, examination and treatment of the person named for up to one month following the date of issue of the second certificate..$^{25}$ One of the certificates must be issued by a doctor on the staff of Alberta Hospital, Ponoka or Alberta Hospital, Edmonton. The other is usually completed by a referring doctor when he fills out the conveyance and examination certificate.

To continue confinement beyond the one month period authorized by the admission certificate, two physicians (or a physician and a therapist) who are of the opinion that the patient is still suffering from mental disorder, dangerous, and unsuitable for continuation elsewhere, following separate examinations, may issue renewal certificates. They authorize detention for a period of six months. ${ }^{26}$

\footnotetext{
19 Designated by Alta. Reg. 163/73, 8. 2.

20 Supra, n. 18, 8. 26.

21 Id., 8. 33.

22 Id., 8. 34.

${ }^{23}$ [1958] S.C.R. 177, 13 D.L.R. (2d) 1, 120 C.C.C. 1 (S.C.C.)

24 Supra, n. 18, 8. 29.

25 Id., s. 30.

26 Id., в. 31 .
} 


\section{Incarceration of the Criminally Insane}

Where a person is charged with the commission of an indictable criminal offence, he may be remanded for a psychiatric examination under $\mathrm{s} .465$ of the Criminal Code ${ }^{27}$ at the preliminary hearing or under s. 543 at trial. Section $465(1)$ (c) allows a justice to remand an accused to such custody as he directs for observation for a period not exceeding thirty days where in his opinion (supported by the evidence of a medical practitioner) the accused may be mentally ill. Pursuant to s. $465(2)$ the accused person may be remanded for up to thirty days where a medical practitioner is not readily available. The remand may be for a period of between thirty and sixty days where the judge is satisfied that observation for such a period is required, and his opinion is supported by the evidence of a medical practitioner.

Under s. 543 of the Code a court may at trial, any time before verdict or sentence, remand the accused to custody for observation where it is of the opinion that the accused person may be mentally ill. This opinion must be supported by the evidence of a medical practitioner. However, he may be remanded for up to thirty days where a doctor is not readily available; or for a period of between thirty and sixty days where the court's opinion is supported by a doctor's evidence. Where a person is charged with an indictable offence there is no provision for a remand for observation before the preliminary inquiry or trial.

If a person is charged with a summary conviction offence, either under the Criminal Code or provincial legislation, ${ }^{28}$ s. 738(5) and (6) allow remands for psychiatric examination. The criteria are the same as those for remand when charged with an indictable offence: the court may, at any time before the sentence, where of the opinion, supported by the evidence of a medical practitioner, that the defendant may be mentally ill (or, if there is no doctor readily available, without such evidence) remand the defendant to custody for observation for a period not exceeding thirty days. Where satisfied that a longer period of observation is required, the court may remand for a period of between thirty and sixty days, but only if supported by evidence of a medical practitioner.

While the Code does not direct where such observation shall take place, s. 50 of the Alberta Mental Health Act states that any person who is remanded into custody pursuant to the Criminal Code may be admitted to, examined and detained in, and discharged from a facility in accordance with the law. In practise all remands into custody for psychiatric examinations are to the maximum security wards of the Forensic Unit at Alberta Hospital, Edmonton (Oliver).

At the trial (of either an indictable or summary conviction offence), the court may, at any time before verdict, direct that an issue be tried as to whether the accused person is then, on account of insanity unfit to stand his trial. The fitness trial may be ordered where there is sufficient reason to doubt that the accused is capable of conducting his defence. ${ }^{29}$ Where the issue arises and the accused person is not represented by counsel, the court must assign counsel to act on his behalf. ${ }^{30}$ If the accused has elected to be tried by judge and jury the issue of fitness to stand trial will be tried by the jury. If the trial is held before a judge or magistrate he will try the fitness

\footnotetext{
2: R.S.C. 1970 , c. C-34 as amended.

24 Summary Convictions Act, R.S.A. 1970, c. 355, s. 5 states that the Criminal Code procedures shall govern.

29 Supra, n. 27, 8. 543(1).

so Id., 8. 543(3).
} 
issue and render a verdict. ${ }^{31}$ When the verdict is that the accused is fit to stand his trial the trial shall proceed as if no such issue had been directed. ${ }^{32}$ When the verdict is that the accused person is unfit to stand trial he is kept in custody until a lieutenant-governor's warrant is issued, authorizing his indeterminate detention in a mental institution. ${ }^{33}$

The court may postpone consideration of the fitness to stand trial of the accused until after the case for the prosecution is completed. If the accused is acquitted at that time, the issue shall not be tried. ${ }^{34}$ However, where an accused person is charged with an indictable offence and the case is to be discharged for want of prosecution, the judge may still order him to be remanded for psychiatric observation and that an issue of his fitness to stand trial be tried. ${ }^{35}$

Assuming that an accused person has not been found unfit to stand trial on account of insanity, he may still be committed on the basis of mental disorder. If the accused is acquitted on the basis that he was insane at the time the offence was committed, the court shall order that the person be kept in strict custody until the pleasure of the lieutenant-governor is known (and a lieutenant-governor's warrant issued). ${ }^{36}$

Where the accused person is found to be insane, pursuant to the Criminal Code (either because he is unfit to stand trial or acquitted of the offence on the ground of insanity) the lieutenant-governor of the province may make an order for the safe custody of the accused (in the Forensic Unit at Alberta Hospital, Edmonton) or, if in the best interests of the accused and not contrary to the public interest, discharge him conditionally or absolutely. ${ }^{37}$ This discharge discretion is very rarely exercised.

As well as the foregoing, there is yet another method by which a person may be confined to a mental institution pursuant to a lieutenant-governor's warrant. The lieutenant-governor of a province, upon evidence satisfactory to him that a person who is insane, mentally ill, mentally deficient or feebleminded is in custody in a prison in that province, may order that a person be removed to a place of safe-keeping named in the order. ${ }^{38}$ The Mental Health Act of Alberta, s. 50(2), provides that any person detained under a warrant of the lieutenant-governor pursuant to the Criminal Code may be admitted to, examined, treated and detained in, and discharged from a facility (Alberta Hospital, Edmonton) in accordance with the law.

The accused person has the right to appeal a verdict of not guilty by reason of insanity or unfit on account of insanity to stand trial to the Court of Appeal and the Supreme Court of Canada. ${ }^{39}$

\section{Ordinary Criminal Procedure}

Confinement under the ordinary criminal procedure usually commences with an arrest by a police officer. A police officer may arrest either pursuant to a warrant issued by a justice or without a warrant where he has reasonable and probable grounds to believe that the person has committed or is about to commit an indictable offence, or is committing a criminal

\footnotetext{
31 Id., 8. 543(4).

${ }^{32}$ Id., s. 543(5).

33 Id., 8. 543(6).

34 Id., 8. 543(4) and (7).

3s Id., 8. 544.

36 Id., 8. 542.

37 Id., 8. 545.

3s Id., 8. 546.

39 Id., 8s. 603 and 620 .
} 
offence. The person may be released upon issue of an appearance notice or summons by the arresting officer or the officer in charge of the lockup.

An accused who has been arrested and not released must be taken before a justice of the peace without unreasonable delay, within 24 hours of arrest unless a justice is not available. If no justice is immediately available the accused person must be brought before a justice as soon as possible to be dealt with according to law. At the hearing (which may be adjourned for up to three days without consent of the accused) the prosecutor must show cause why the accused person shall not be released upon his undertaking to appear at trial. The order of the justice may be reviewed by a judge.

If the accused person, charged with an indictable offence, is not released by the justice, the person having custody of the accused is required to apply for a hearing before the expiration of 90 days to determine whether or not the accused should be released or his trial expedited. If the offence is punishable on summary conviction, the application must be brought within 30 days.

With the exception of certain indictable offences within the absolute jurisdiction of a magistrate, ${ }^{40}$ the accused has the right to elect trial by magistrate, by judge alone, or by judge and jury. He is then entitled to a trial on the issue of whether or not he committed the offence, with the prosecution carrying the burden of proof. If found guilty, he may be sentenced to a specified number of years imprisonment, the maximum sentence varying, depending upon the offence committed. He then has a right of appeal to the Court of Appeal, and in certain circumstances to the Supreme Court of Canada.

\section{B. Due Process Aspects \\ 1. Criteria of Confinement}

It has been necessary to briefly set out the procedures for depriving people of their freedom for being mentally disordered, or for being accused or guilty of a criminal offence before discussing the fairness or justice of each of the processes. Perhaps the best place to start is to look at the reasons for involuntary confinement and the criteria utilized in deciding whether or not to confine.

To be certificated as a formal (involuntary) mental patient a person must be suffering from mental disorder, in a condition presenting a danger to himself or others, and be unsuitable for admission to an institution as other than a formal patient. These criteria should be examined one by one. "Mental disorder" is defined by the Mental Health Act"1 to mean "lack of reason or lack of control of behaviour."42 While this definition appears to be almost as much in need of explanation as the phrase that it defines, it is as helpful as the definitions found in other provinces' mental health legislation. ${ }^{43}$ There has been no judicial interpretation of the words "mental disorder." However, the English Court of Appeal has stated that the words "mental illness" are ordinary words of the English language and have no particular medical or legal significance. They should be construed in the way that ordinary sensible people would construe them. The court states

10 Id., s. 483.

1" Supra, n. 18.

12 Id., 8. 1(i).

43 Ontario Mental Health Act, R.S.O. 1970, c. 269, 8. 1; New Brunswick Mental Health Act, N.B.A. 1969, c. 13, 8. 1(g) P.E.I. Mental Health Act, 17 Eliz. II, c. 37 as amended 18 Eliz. II, c. 28, s. 1; Newfoundland Mental Health Act, S.N. 1971, No. 80, s. 2; Saskatchewan Mental Health Act, R.S.S. 1965, c. 345 as amended S.S. 1970, c. 43; Manitoba Mental Health Act, R.S.M. 1970, c. 48 as amended. 
that the test is what the ordinary sensible person would have said about the fellow. 44

This definition of mental illness (or mental disorder) perhaps overly minimizes the expertise of medical pratitioners, but it recognizes an important fact: mental disorder is not a purely medical phenomenon. To a large extent, defining a person as mentally disordered is an assertion that his behaviour deviates from what the examiner or observer feels to be "normal" human behaviour and that he is unable to cope with his social environment. The problem is that the definition of "normal behaviour" reflects the moral, social, political and economic values of the assessor. In view of this, it is rather surprising that determining what constitutes mental disorder has been so completely left to the discretion of individual doctors. Many of the doctors signing admission certificates have little psychiatric training, and the justifications for commitment included on the admission certificate (or more usually, not included) lead one to wonder how often compulsory admission is implemented on largely non-medical grounds.

As well as suffering mental disorder, a person must be dangerous to himself or others. This issue was considered by the Quebec Court of Appeal in Dame L. v. Larue. ${ }^{45}$ The court defined danger as the threat of physical or other serious damage to oneself or others. Montgomery J. states:46

Is it necessary that petitioner be kept in the hospital for her own protection? . . It is not seriously suggested that there is any danger to her welfare in releasing her unless she should fail to take regulardoses of insulin and there is nothing in the record to indicate that there is any serious reason to apprehend that this would occur. . . .

Is it necessary that petitioner be confined for the protection of society? It is recognized by all the doctors who testified that she is not dangerous in the sense of threatening to inflict physical violence upon anyone. There is no evidence that she ever became violent, even at those times when her mental disturbance was in its most acute form. Respondent and the members of his staff who testified suggested, however, that her conduct might be dangerous in the sense of being antisocial and damaging to her husband. . . .

Even if petitioner should write letters or make telephone calls denouncing her husband, there is nothing in the record to indicate that he would suffer anything worse than social embarrassment from such denunciations.

There are two interesting moral questions raised by these criteria. The first relates to the "danger to oneself" as justification for detention. What right has society to deny an individual's freedom because he is a danger to himself? One viewpoint suggests that if a person wants to die, he has a right to commit suicide and that no one else is justified in interfering with that action. On the other side, it can be argued that society has a right to protect itself by preventing its individual members from killing themselves. More to the point, hospital staff involved in the treatment of depressed persons threatening suicide cite the instances where those same people came up to them some months or a year later to thank the staff for preventing their suicides, saying that they did not realize at the time that they had so much to live for. To what extent we are our brother's keeper is a moral issue, and the Legislature has decided that we have a responsibility for the lives of our neighbours.

The other moral question raised is as to the validity of confinement on the basis of two doctors' opinions that a person is dangerous to others. A person is confined not for what he has done, but for what he might do. This is in contrast to incarceration under the Criminal Code where a person must be

\footnotetext{
“ W. v. L. [1973] 3 All E.R. 884, [1973] 3 W.L.R. 859 (C.A.).

is [1959] Que. Q.B. 549 (Que. C.A.).

16 Id., at 554-5.
} 
convicted of the commission of a specific offence before he can be sentenced to a term of imprisonment. A widely quoted article in the Harvard Law Review ${ }^{47}$ makes the point that no court would base a criminal's conviction upon a medical expert's prognostication that the accused was $80 \%$ likely to commit an unlawful act, yet that same $80 \%$ prediction applied to someone suffering from severe psychosis will invariably lead to detention.

The usual absence of any specific dangerous act suggests that the patient is being committed largely because of his status. It seems to be assumed that even if the patient is not really dangerous he is mentally disordered and will therefore benefit from treatment. It also appears to be partly based on ignorance of the strange-seeming thought process of the mentally ill, and a fear that they lack the capacity to be deterred by criminal penalties. On the one hand is the very strong argument that such a serious infringement of the individual's rights as deprivation of his freedom must be based upon more than mere opinion (the Act permits the doctor to use hearsay evidence). But on the other hand is the compelling argument against allowing a severe psychopath whose dangerousness is evident to everyone coming in contact with him to remain free to murder his wife in the honest but unfounded and paranoid belief that she was scheming to poison him. What about her right to life?

In any event, it is suggested that if persons are to be deprived of their liberty on mere predictions of danger to society, great care should be taken to make certain that those predictions are carefully and copiously justified. As will be indicated later, this presently is not the case.

The final criterion for coerced admission to a mental institution is that the patient not be suitable for admission other than as a formal (involuntary) patient. The intent of this requirement seems to be to prevent two admission certificates from being filled out for every patient entering one of the Alberta Hospitals-“just in case." Theoretically it puts the onus upon the admitting doctors to justify why compulsory admission was necessary, but its practical effect appears to have been minimal.

Before a patient can be incarcerated for mental disorder pursuant to the Criminal Code he must have been charged with an offence. He is alleged to have infringed a specific statutory prohibition. Compare this with civil commitment where it is enough that a person be mentally disordered and (probably) dangerous to himself or to others. However, here the insanity provisions of the Code part with the detention procedures for other alleged offenders of the criminal law. Once a person has been accused of a crime, to justify detention it is enough to show that he is or was insane. He is thus confined because of his status again, rather than for what he has done.

Once a person is charged with an offence, the opinion of a judge that he might be mentally ill, supported by the evidence of a medical practitioner, is sufficient to remand him for observation (and, according to $\mathrm{s}$. 50(1) of the Alberta Mental Health Act, treatment and care). It is difficult to criticize the provision of a power of remand for psychiatric examination, however, because a significant number of persons who commit crimes are mentally unbalanced and it is better that they be examined in a mental hospital than in the courtroom or at a provincial jail. The medical opinion is valuable in the courts' determination of the fitness of the accused for trial or whether he should be acquitted on account of insanity.

The first instance in which an accused person can be detained under a

"Civil Commitment of the Mentally Ill: Theories and Procedures, (1965-66) 79 Harvard Law Review 1288. 
lieutenant-governor's warrant is if he is found to be unfit to stand his trial on account of insanity. The fitness rule is justified on three main grounds. ${ }^{48}$ The first is to ensure the accuracy of the trial. In an adversarial proceeding such as a criminal trial, if the accused is mentally unable to defend himself or to instruct counsel the trial will not be fair. Also, the accused may, because of his mental disorder, not reveal facts within his own knowledge which would exonerate him if disclosed. While this is certainly an important and valid reason for testing the mental fitness of the accused one wonders why it is often done at the outset of the proceeding rather than delayed until the merits of the charge have been inquired into. One suspects that the accused is being confined, not because he is unfit to stand trial, but because of his status as a mentally disordered person.

A second reason for not trying a mentally disordered person on the charge is because his possibly bizarre or frivolous behaviour might infringe upon the dignity of the proceedings. One suspects that this is one of the real reasons for the inclusion of s. 577 in the Criminal Code, which permits a court to exclude an accused from the trial of the fitness issue itself purportedly because remaining might have an adverse effect on the mental health of the accused. Although respect for the court is important, concepts of what should constitute courtroom decorum alone should not preclude the accused person from having some opportunity to have his innocence demonstrated.

The third general ground justifying the fitness rule is that it is generally considered morally wrong to try and punish an individual who has no appreciation of what is happening to him. Because he may have no conception of the reprehensibility of his conduct, punishment and deterrence may be lost upon the mentally unfit accused. However, in considering this justification one should realize that it is not the trial from which the accused should be protected, but against the punitive consequences of being convicted.

The justifications advanced for the rule indicate that some form of fitness rule is necessary to ensure a fair trial and to protect a mentally disordered accused person from punitive consequences when he has no appreciation of the moral reprehensibility of his conduct. However, it also appears evident that there is no real reason for trial of the fitness issue prior to trial on the merits other than possibly to preserve the decorum of the court. In fact, decision on the fitness issue prior to some determination of the validity could result in indeterminate confinement of innocent accused persons merely because of their mentally disordered status. This is certainly not a valid reason for detention under the criminal law, especially if the person would not be certifiable under provincial civil commitment legislation.

A person can also be detained under a lieutenant-governor's warrant if he is acquitted of an offence on the basis of insanity. The elements of the "defence" are set out in s. 16 of the Code. Everyone is assumed to be sane until proven otherwise. A person is considered to be insane when he is in a state of natural imbecility or has disease of the mind to an extent rendering him incapable of appreciating the nature and quality of an act or omission or of knowing that it is wrong.

The term "natural imbecility" appears to refer to a person who is mentally defective or severely mentally retarded. The words "disease of the mind" apparently refer to mental disorder, which must be to the extent of

40 See: Law Reform Commission of Canada, Fitness to Stand Trial, 1973 (study paper). 
rendering him unable to appreciate that he committed the act or omission he did or, if he comprehends the act, unable to understand that it was morally and legally wrong. The provision further states that a person who suffers from specific delusions but is otherwise sane will only be acquitted if the delusions caused him to believe in the existence of a state of things which would have justified or excused his act or omission had that state existed.

The acquittal on the basis of insanity rests upon the criminal theory that a person cannot be guilty of an offence if he did not possess the requisite guilty intent or mens rea. A person who did not know that his actions or omissions were wrong cannot be convicted of the crime.

It must be remembered that in the past, insanity was often considered by the accused to be a defence. This was because crimes such as murder were punishable by death. Indefinite detention in a mental institution was considered preferable to the hangman's noose. Nevertheless, today many criminals would prefer a defined prison term (even life imprisonment) with the possibility of parole, to indeterminate confinement in a mental hospital. Whereas detention because of insanity at the time the offence was committed was once less severe than the criminal penalty, today it may be a more serious abrogation of the freedom of the accused person.

It may well be that a person who was insane at the time he committed a criminal offence should be treated differently than the usual convict. The punishment of depriving the insane child molester, for example, of his liberty for a specified period of time may have no effect on him because he does not realize that it is wrong to kill little girls, or because he cannot control himself. Also the supposed rehabilitation which takes place in the prison or penitentiary will likely be totally inadequate to treat a person suffering from severe mental disability. Therefore, it is clear that they must be detained where they are not a major threat to public safety and where they can receive whatever treatment is available for their form of mental disorder. Here, the matter of confinement is not a contentious issue for they have clearly demonstrated themselves to be dangerous to society. The question resolves itself more to the procedure of ensuring the most equitable treatment for both the person found to be insane and society.

Under the Criminal Code a person can only be convicted of having committed a specific prohibited offence. He can then be sentenced to imprisonment, resulting in a loss of liberty for a specified period of time. It should be noted in considering detention as a result of mental disorder that the person is incarcerated for what he has done only in one instance-where he is found not guilty of an offence because of insanity. In other situations of detention-because of unfitness to stand trial, on remand, and as a result of civil commitment-the person is committed for what he is rather than for what he has done. It is submitted that where abrogation of freedom is authorized on the basis of status great care must be taken in defining that status. Otherwise it is far too easy to lump into that category people who do not belong there. One method of achieving this limitation is by a careful definition of the criteria by which people are declared subject to confinement, and the other method is by a strict delineation of the procedure by which that judgment is reached in the individual case.

Presently the definition of what would constitute a person unfit to stand trial because of insanity is extremely vague. Considering that the effect of a declaration of unfitness, indeterminate detention, is potentially more severe than the maximum sentence for most criminal offences, the criteria are unacceptably vague. This is especially so when one remembers that the 
subject of the fitness hearing has been convicted of no offence. It has not been proved that he committed the act of which he is accused.

While the definition of mental disorder for the purpose of civil commitment is extremely vague, more detailed definitions in other provinces' mental health legislation do not seem to be very much better. However, a somewhat more detailed definition might at least aid in determining what forms of abnormal or eccentric behaviour are not categories for which one might be involuntarily detained.

\section{Procedure of Confinement}

The initial procedure for detaining a person so that his mental state (or in the criminal field, his guilt) can be determined is fairly reasonable. In the civil commitment area the use of the conveyance and examination certificate, the order for apprehension and the police emergency "arrest" power are obviously necessary to enable examination of the allegedly mentally disordered and dangerous individual. They are analogous to the police arrest powers under the Criminal Code (which apply to both the criminally insane and the ordinary criminal).

The most striking divergences in procedure occur where the actual application of the detention criteria occurs. To be detained under the Mental Health Act one must be examined and certified by two doctors. Schmidt $\mathbf{v}$. Katz \& Shnider ${ }^{49}$ held that certification on the basis of a telephone conversation with the patient's mother was insufficient and that personal examination is required. But it was held in Williams v. Ballam ${ }^{50}$ that climbing into an ambulance and talking with the person for 2 to 5 minutes was sufficient examination for the purpose of the B.C. Mental Health Act. Examination of admission certificates completed by doctors, authorizing detention under the Alberta Mental Health Act shows them to be extremely poorly filled out and including very little information.

Contrast this procedure with the Criminal Code provisions for dealing with suspected criminals. The accused person must be brought before a judge within 24 hours where the prosecution must show cause why he should not be released pending trial. Then he is entitled to $a$ fair and open trial of his guilt before an impartial judge (and for some offences, a jury, if he so elects). He has the right to counsel and the prosecution carries the burden of proving his guilt before he can be convicted and sentenced. This is a far cry from two brief examinations by physicians. One is usually untrained in psychiatry, and the other usually makes his examination in the crowded admissions area of a mental hospital.

A person charged with a criminal offence is entitled to a fair hearing of his case before an impartial tribunal. A person alleged to be mentally disordered is "examined" by two doctors, each of whom is prosecutor, judge and jury. The analogous situation under the Criminal Code would be if an accused was sentenced following interrogation by two police officers, each of whom subsequently certified him to be guilty of the offence. Surely the police officers are experts in the area of crime to an even greater extent than physicians (except perhaps psychiatrists) are in the field of mental disorder. If some sort of impartial hearing at which the defendant can present a defence is deemed necessary in the first instance why not in the second? Perhaps an adversary procedure to the extent found in the criminal

19 (1954) 13 W.W.R. 654 (Sask. Q.B.). See also X. v. Y.|1970|Que. C.A. 795 for a similar decision under the Quebec Civil Code.

so (1964) 45 D.L.R. (2d) 284, 48 W.W.R. 182 (B.C.C.A.). 
law is unnecessary and undesirable in civil commitment procedures, but when one recalls that detention is on the basis of mere opinion as to the patient's state of mind and usually only a prediction of his dangerousness, the present procedure appears incredibly sloppy.

Detention under the Criminal Code on the basis of mental disorder usually begins with a remand to custody for observation because of the possible mental illness of the accused. The courts have held that a magistrate can only remand an accused person for observation if the accused is appearing before him. Ex parte remands are illegal and an order in the nature of habeas corpus will be granted. ${ }^{51}$ Thus the accused is assured of a fair hearing before remand can take place. However, the period for remand (up to 60 days) appears to be an inordinately long period to detain a person not yet convicted of any offence, merely for psychiatric examination. Under the Mental Health Act such examinations can apparently take place in about 5 minutes!

Although the remand is valid for 30 to 60 days, the practice in Alberta appears to be to return the accused to court when the assessment is finished, often after 10 to 14 days of psychiatric assessment. While it is clear that if the accused is detained beyond the remand period an order in the nature of habeas corpus will be granted, ${ }^{52}$ one wonders why the period need be so long.

Until recently, s. 546 of the Code was abused by the issue of lieutenantgovernor's warrants in respect of accused persons on remand to a provincial mental health facility. In $R$. v. Sayle ${ }^{53}$ however, Munroe J. held that such administratively imposed detention was contrary to the due process and fair hearing provisions of the Canadian Bill of Rights. Before a lieutenantgovernor's warrant can be issued respecting an accused on remand he is entitled to have his fitness to stand trial tested in court. It is obvious that to hold otherwise would permit confinement at the pleasure of administrative authorities, contrary to most conceptions of due process.

There is also some judicial authority to the effect that when a person is remanded to a provincial mental health facility under the Code he cannot be denied his right to a fair hearing of his fitness to stand trial by certification under provincial mental health legislation..$^{54}$ Certification under the Mental Health Act would deprive the accused of a trial to test his fitness, and could even be an infringement of Parliament's constitutional jurisdiction over the criminal law.

The point at which the issue of fitness to stand trial should be determined was briefly raised earlier. If the main justification and reasons for the fitness issue are fairness to the accused and the immorality and pointlessness of punishing someone mentally unaware of the wrongness of his actions, then perhaps determination of the fitness question should be delayed. The Law Reform Commission of Canada suggests that the trial judge have the discretion to postpone the issue until after presentation of the case for the prosecution or until after completion of the trial to

\footnotetext{
s) Re Sarault (1905) 9 C.C.C. 448 (Que. K.B.); R. v. Bouchard (1912) 20 C.C.C. 95 (Que. Sess. C.).

32 Trenholm v. A.G. Ontario [1940] S.C.R. 301, [1940] D.L.R. 497 (S.C.C.); Dame R. v. Johnson [1946] Que. S.C. 101 (Que. C.S.)

33 R. v. Sayle [1974] 5 W.W.R. 766,18 C.C.C. (2d) 56 (B.C.S.C.).

is R. Leys (1910) 1 O.W.N.958(Ont.C.A.); R. v. Atwood (1972)7 C.C.C. (2d)116(N.W.T. Mag. C.). Fawcett v. A.G. Ontario[ 1964 ]S.C.R. 625,45 D. L.R. (2d) 579 (S.C.C.), which heldOntario mental health legislation authorizing a judge to commit a person appearing before him to be valid, is distinguishable. The court stated that if the provincial legislation had been in conflict with the Criminal Code 80 as to bring about a different result (as issuing admission certificates surely would), the Code would have prevailed.
} 
allow the accused the possibility of an acquittal on the merits of the case. $^{55}$

It is suggested here that the most equitable method of considering the fitness of the accused to stand trial would be normally to raise the issue at the end of the case for the prosecution. If represented by counsel, the ability of the accused to understand what is going on is largely irrelevant to presentation of the Crown's case. If the prosecution failed to present sufficient evidence that the accused committed an offence, he would be acquitted. The trial judge could have discretion to advance hearing of the fitness issue to the opening of the trial or delay it until after completion of the trial. This contrasts with present discretion to delay it until the opening of the defence. The reason for requiring an exercise of discretion to conduct the fitness trial before any trial on the merits is to increase the likelihood of some consideration of the merits of the charge. It also emphasizes that the purpose of the declaration of unfitness to stand trial on account of insanity is for the benefit of the accused person, and not merely another means of securing indeterminate confinement of suspected dangerous mentally disordered persons.

The treatment of someone acquitted of an offence on the basis of insanity appears fairer than most of the procedures previously discussed. The person has had the opportunity to present his side of the case (whether pleading insanity or denying it) before a court, including the presentation of medical evidence. The only possible area of concern is the ease with which a person acquitted of committing the offence on the ground of insanity is presumed to be still insane and a lieutenant-governor's warrant therefore issued.

An alternative to commitment under a lieutenant-governor's warrant, authorized by s. 545 of the Code, which is likely underutilized, is the conditional discharge of the insane person. This could include outpatient treatment at a mental or general hospital. As well, s. 49 of the Mental Health Act permits a judge to order a person appearing before him to attend a mental health facility or service as an outpatient. If the safety of the public would not thereby be endangered these alternatives involve a much lesser infringement of the liberty of a mentally disordered individual.

Finally, s. 546 of the Criminal Code authorizes issue of a lieutenantgovernor's warrant respecting a person in custody in a prison when he believes the prisoner to be insane, mentally ill or mentally deficient. This exchange of a determined sentence for an indeterminate period of confinement could clearly work to the disadvantage of the prisoner. Therefore, it was held in $R$. v. Sayle $e^{56}$ that the prisoner is entitled to have his sanity tested before the court before a warrant can be issued under s. 546 .

\section{RELEASE}

\section{A. Procedure}

\section{For Civilly Committed Patients}

If it is relatively easy to be involuntarily committed to a mental hospital under the Mental Health Act, it is equally as simple to be released. Section 48(3) of the Mental Health Act permits the staff to discharge an involuntarily detained patient where he is no longer a danger to himself or others. The hospital will normally give notice of the discharge to the patient's nearest relative and to the referring source (usually a doctor). 
The Act provides that wherever admission or renewal certificates are issued in respect of any patient, the patient must be given a written statement of the function of the review panel, the name and address of the chairman of the appropriate review panel and of his right to apply to the review panel for cancellation of his admission or renewal certificates. ${ }^{57}$

A formal (involuntary) patient or a person acting on his behalf may apply to a review panel for cancellation of his certificates a maximum of two times per year. ${ }^{58}$ The applicant must be heard within 28 days, or such longer period as the Minister of Health and Social Development allows. ${ }^{59}$ The review panel is then to carry out whatever investigation and hearing it considers necessary to determine the issue.60

The proceedings of a review panel are conducted in private, subject to the discretion of the chairman. However, the applicant can be excluded from the hearing if the review panel believes that his presence may have an adverse effect on his health. In that event a person must be appointed to act on his behalf.61

The review panel has discretion to refuse the application, discharge the patient completely, or discharge the patient with certain conditions attached. ${ }^{62}$ The panel consists of four members. One member must be a psychiatrist, one a physician, one a lay representative of the general public, and the chairman (with the casting vote) must be a solicitor. ${ }^{63} \mathrm{~A}$ person convicted of a criminal offence who is committed to a mental health facility for treatment may also apply to the review panel for transfer back to the correctional institution. ${ }^{64}$

The applicant has an appeal from the review panel decision to the Alberta Supreme Court.65

\section{For the Criminally Insane Patient}

The Criminal Code outlines in s. 547 the review and release procedure for persons detained at the pleasure of the lieutenant-governor, who can only be released by the lieutenant-governor. However, each case is reviewed every six months by a review board appointed by the lieutenant-governor of the province. The board must consist of between three and five members, at least one of whom must be a psychiatrist and at least one of whom must be a lawyer.

The review board then makes a recommendation respecting the patient to the lieutenant-governor. If the patient was found unfit on account of insanity to stand trial, the board recommends whether he has recovered sufficiently to stand trial. Where the person in custody was acquitted on the basis of insanity, the board reports whether in its opinion the person has recovered and whether it is in the public interest to discharge the prisoner either absolutely or conditionally. The board also recommends whether a person transferred from a prison under s. 546 of the Code has fully or partially recovered so that he may be returned to the prison.

\footnotetext{
st Supra, n. 18, s. 36.

38 Ld., 8. 38.

so Id., 8. 41(1).

Bo Id., 8. 39.

61 Id., 8. 40.

62 Id., 8. 41(2)

6.3 Id., 8. 19.

of Id., 8. 42.

as Id., 8. 46.
} 
The Federal Court of Canada can review decisions of a review board and grant declaratory relief to a prisoner.66 The court has declared that the meaning of "recovered" for the purpose of release requires more than that the prisoner is no longer insane within the meaning of $s .16$ of the Code. The prisoner must have fully recovered his sanity so that he is no longer a danger to the public. ${ }^{67}$

\section{For the Ordinary Criminal}

Unless he is sentenced to a term of life imprisonment, after a criminal has served the period of detention specified in his sentence he must be released. He has also a right to apply for earlier release to the National Parole Board, apart from statutory remission of part of his sentence.

\section{B. Due Process Aspects}

The primary distinction between the provincial and the criminal review and release provisions is that under the Mental Health Act release can be either an administrative or judicial procedure whereas the Criminal Code makes release a judicial matter. The requirement that the release procedure for persons detained pursuant to the criminal process be of a formal judicial nature is certainly justifiable. The prisoners have been arrested and detained on the basis of having committed a crime. Therefore, their dangerousness to the security of the public is a question requiring very careful thought. Yet this difficulty in securing release is still another argument in favour of having some trial on the merits of the charge before the question of fitness to stand trial is decided.

In view of the earlier suggestion in this paper that the involuntary admission procedure to mental institutions should be more formalized to accord with basic conceptions of due process, one might expect a similar recommendation with respect to release. Nevertheless, such a suggestion does not logically follow. The reason for this goes back to the fact that involuntary detention under the Mental Health Act is usually based upon mere prediction of dangerousness, a notoriously inaccurate basis. In the absence of a specific previous anti-social dangerous act, administrative discretion in the matter of discharge is justifiable, in addition to a judicial form of review by a review panel.

It is also worthy of note that the review of the patient detained under the Code is automatic whereas a patient must apply to the Mental Health Act review panel. Clearly, periodic review is of vital necessity. Horror stories of persons locked away in mental institutions and then forgotten are not unknown.

The best method of review would be to require the provincial review panel to automatically examine every involuntarily detained patient at periodic intervals. In opposition to this view it has been argued that there are too many such patients to make a review feasible, and that the patients must be reviewed at least every six months by the physicians signing the renewal certificates. For this argument to be valid, the doctors signing the renewal certificates must conduct a thorough examination of the patient and not regard completion of the renewal certificates as merely a pile of legalistic paperwork.

The provincial review panel is given authority to decide whether or not a patient should be discharged whereas the federal review board can only

\footnotetext{
th Lingley v. Hickman (1973) 33 D.L.R. (3d) 593 (Fed. C.).

67 Lingley v. N.B. Board of Review (1973) 13 C.C.C. (2d) 303 (Fed. C.).
} 
recommend to the lieutenant-governor. The limitation on the review board's authority appears to be for reasons of constitutional law and of little practical consequence. In Alberta, the review board has frequently exercised more effective control than the supposedly more authoritative review panels.

The provisions for private hearings of the review panel and exclusion of the applicant from the hearing are quite contrary to due process. Historically, the reason for open trials in the criminal law was to ensure that the accused was treated fairly. In closed session the review panel can be much less vigilant in respecting the patient's rights than in a hearing open to the public. It is true that private sessions protect the privacy of the applicant and his relatives, who may not want the world to know that he is being detained for mental disorder. Notwithstanding, that right can be protected by giving the applicant the option of a closed or open hearing. While the reason for excluding the applicant from a hearing may be concern for his mental health it has also been done for the convenience and perceived safety of those opposing his release. Probably the single most important failure of the review system to live up to the due process consideration in a practical sense is the almost blanket provision for closed hearings.

An order in the nature of habeas corpus is available to secure a hearing for release where the provisions of the Mental Health Act or the Criminal Code are breached. However, the extent and circumstances of this review are not a part of this study.

\section{THE BILL OF RIGHTS}

\section{A. Canadian Bill of Rights}

It has been firmly established by $R$. v. Drybones ${ }^{68}$ and subsequent cases ${ }^{69}$ that the Canadian Bill of Rights will render inoperative federal statutory provisions that conflict with any of the rights and freedoms therein declared. The Supreme Court of Canada has also interpreted the expressly prohibited forms of discrimination (by reason of race, national origin, colour, religion or sex) in s. 1 to be merely examples of reasons for which individuals cannot be denied due process of law, equality before the law, etc. ${ }^{70}$ Therefore, a federal statute denying a mentally disordered person any of the rights and freedoms declared in s. 1 of the Canadian Bill of Rights may be held inoperative if it cannot be construed so as to avoid abrogating those rights.

The scope of the due process provision in $\mathrm{s} .1$ has been discussed in Part I of this paper. Laskin J. considers it to have a definite procedural aspect, and possibly a substantive aspect as well. The right not to be deprived of liberty except by due process of law was applied by Monroe J. in $R$. v. Sayle ${ }^{71}$ to prevent the issue of a lieutenant-governor's warrant in respect of a person on remand under s. 546 of the Criminal Code. The court held that the warrant could not issue until the fitness of the accused for trial was tested in court if he was to be accorded his right to due process and a fair hearing.

According to Laskin J. most if not all of the procedural protection of $\mathbf{s}$. 1(a) (due process) is covered in $\mathbf{s .} 2$ of the federal Bill of Rights. However,

be [1970] S.C.R. 282, 9 D.L.R. (3d) 473, ]1970] 1 C.C.C. 355, 10 C.R.N.S. 334 (S.C.C.).

69 Curr v. R., supra, n. 11; A.G. Canada v. Lavell (1974) 38 D.L.R. (3d) 481, 23 C.R.N.S. 197 (S.C.C.); Brownridge v. $R$. (1972) 28 D.L.R. (3d) 1, 18 C.R.N.S. 308, 7 C.C.C. (2d) 417 (S.C.C.); R. v. Burnshine (1974) 25 C.R.N.S. 270 (S.C.C.); A.G. Canada v. Canard (1975) 52 D.L.R. (3d) 548 (S.C.C.).

io Supra, n. 11.

"Supra, n. 53. 
where it could be applied in a substantive matter is uncertain. An example might be if a remand for observation of over 30 days was invalidated because such a lengthy period of confinement before determination of guilt or innocence would be an unfair treatment of the allegedly mentally disordered person compared to treatment of the ordinary criminal. Another example could be where a trial of the mental fitness of the accused person before a trial on the merits was invalidated because to do so would deprive the allegedly mentally disordered person of the possibility of an acquittal on the merits. However, the Supreme Court has indicated that such arguments must be very well substantiated if they are to succeed.

The right to equality before the law and the protection of the law falls within the range of a broad concept of abstract due process. The Supreme Court of Canada has indicated in A.G. Canada v. Lavell, R. v. Burnshine, and A.G. Canada v. Canard that "equality before the law" as expressed in the Canadian Bill of Rights is going to be interpreted in a very strict manner. ${ }^{72}$ It is fairly safe to say that the Criminal Code insanity provisions will not be declared inoperative merely because they discriminate against mentally disordered people (although the "equality before the law" argument could be used in support of the substantive due process examples above-that such discriminatory treatment of criminals on the basis of mental disorder is unjustifiable). The Supreme Court decided in $R$. v. Burnshine ${ }^{73}$ that indeterminate prison sentences for habitual offenders did not deny them equality before the law. The court said that the indeterminate sentence was for the benefit of the offender, and that Parliament was seeking to achieve a valid federal objective with the legislation. It was not enough to invalidate the legislation that it applied to only one class of persons. The same reasoning would no doubt be applied in indefinite detention under a lieutenant-governor's warrant.

$\bar{E} x$ parte Kleiny $7^{74}$ decided that detention at the pleasure of the lieutenant-governor is not arbitrary detention, contrary to s. 2(a) of the Canadian Bill of Rights. This decision was justified on the basis that the detention merely rests upon the discretion of the lieutenant-governor, to whom application may be made at any time for release. As well, there is an automatic review of the confinement at least once every six months. $R$. v. Hatchwell ${ }^{75}$ also held that detention for an indefinite period subject only to the discretion of a reviewing board (in that case the Parole Board) is not arbitrary detention.

Indeterminate detention, such as under a lieutenant-governor's warrant has also been held not to be cruel and unusual treatment or punishment within the meaning of the federal Bill of Rights. ${ }^{76}$ Obviously, the Canadian courts are not prepared to strike down indefinite detention provisions such as those authorizing a lieutenant-governor's warrant.

It is evident from s. 2(c)(ii) of the Bill of Rights that a person alleged to be mentally disordered has a right to counsel when appearing before a judge prior to remand, at a trial of his mental fitness to stand trial, at his trial (where the insanity issue may be raised), and when he is appearing before

72 Supra, n. 69.

73 Supra, n. 69. See also Pearson v. Lecarre, S.C.C. Bulletin 5/10/73, p. 309 (S.C.C.); R. v. Hatchwell[1974] 1 W.W.R., 307, 14 C.C.C. (2d) 557 (B.C.C.A.).

${ }^{74}$ [1965] 3 C.C.C. 102, 49 D.L.R. (2d) 225 (B.C.S.C.)

73 Supra, n. 73.

70 Ex parte Kleiny's, supra, n. 74; R. v. Buckley[1970] 2O.R. 614,[1970] 2C.C.C.4 (Ont. Prov. C.); R. v. Roestad [1972] 1 O.R. 815, 19 C.R.N.S. 190, 5 C.C.C. (2d) 469 (Ont. Co. C.), R. v. Hatchwell, supra, n. 73. 
the review board. The practice is to give the accused person access to counsel at all of these stages.

Section 2(c)(iii) declares that a detained person has the right to a determination of the validity of his detention by way of habeas corpus. The common law position is that detention at the pleasure of the lieutenantgovernor is not reviewable on habeas corpus, except in limited circumstances. Ex parte Kleiny held that s. 2(c)(iii) did not change this. However, the court gave no reason for ignoring the clear wording of $s$. 2(c)(iii) in favour of the old common law position. It is submitted that, in view of the cases, such as Drybones, decided after the determination of the B.C. Supreme Court was rendered in Kleiny, there is indeed a right to review by habeas corpus. With the creation of the review boards in the last few years, though, the remedy would likely be of slim practical value.

$R$. v. Atwood ${ }^{77}$ held that a person charged with a criminal offence has the right to a trial (at least of the fitness issue), and that the right to a fair hearing guaranteed by $\mathrm{s}$. 2(e) includes the right not to be spirited away by being declared mentally disordered under civil mental health legislation. Taken with the Sayle decision, this should prevent accused persons remanded out to Alberta Hospital, Edmonton from being certificated under the Mental Health Act, and never getting back before the court.

There is considerable scope for use of the Canadian Bill of Rights to aid persons detained for insanity under the Criminal Code. It is obvious that legislation authorizing indeterminate detention is valid legislation, although $R$. v. Sayle guarantees the right to a fair hearing before issue of a lieutenant-governor's warrant. Nonetheless, the utility of the federal Bill of Rights will depend to a large degree on development of the s. 1(a) due process clause.

\section{B. Alberta Bill of Rights}

The mode of interpretation of the Alberta Bill of Rights has been discussed previously in Part I. It seems proper to apply the jurisprudence surrounding the Canadian Bill of Rights in the absence of authoritative decisions on the Alberta Act. In Flint Engineering v. United Brotherhood of Carpenters \& Joiners, ${ }^{78}$ Kirby J. considered s. 1(e) of the Alberta Bill of Rights. It could be argued that his judgment implies that the Act only prevents discrimination on the expressed grounds (race, national origin, colour, religion or sex). However, it would be surprising if this could be said to displace the explicit statements of the Supreme Court of Canada in Curr and Burnshine.

Similarly, in Bachinsky v. Sawyer ${ }^{79}$ Shannon J. held that the Alberta Bill of Rights guarantees no right to counsel because it is not stated explicitly in the Act. However, he failed to consider the analyses of the Supreme Court of Canada in Lowry \& Lepper v. $R$. and Curr v. R., examined earlier in the paper, or the wording of the Acts. He did not conduct an indepth analysis of the issue, but dismissed it instead summarily. It is submitted that the phrase "due process" in s. 1(a) of the provincial Bill of Rights contains at least the right to a fair hearing before an impartial tribunal as stated by Laskin J. in Curr; and that, in fact, the particularizations in s. 2 of the federal Bill of Rights are implied in s. 1 of the Alberta Bill of Rights.

it Supra, n. 54.

is (1974) 41 D.L.R. (3d) 100 (Alta. S.C.).

79 (1974) 43 D.L.R. (3d) 96, 14 C.C.C. (2d) 401 (Alta. S.C.). 
The involuntary admission procedures in ss. 29 and 30 of the Mental Heal th Act appear to be contrary to the Alberta Bill of Rights guarantee that the right to liberty can only be deprived by due process of law. In Curr v. $R$., Laskin J. said that due process includes at least the right to a fair hearing in accordance with the principles of fundamental justice before an independent and impartial tribunal. Two medical doctors signing separate admission certificates after brief examinations hardly constitutes a fair hearing before an impartial tribunal. The examination is usually a discussion with the prospective patient, and observation of his deportment and mannerisms. As discussed earlier, the doctor plays the role of prosecutor, judge and jury, and there is no opportunity for the allegedly disordered person to present his side of the issue by calling evidence or through counsel. Examination by the doctor is no more a fair hearing than is interrogation by the police.

The fact that the certificated patient can apply to the review panel is not relevant. It is an appeal by the patient against the operative procedure authorizing detention. To constitute due process, the hearing must be a condition precedent to removal of the right to liberty and not something for which the individual must ask after freedom is lost. To hold otherwise relegates liberty, from a right, to a mere privilege.

The foregoing is a rather startling revelation, but the response should not be to amend the Mental Health Act so that it operates notwithstanding the Alberta Bill of Rights. A more rational reaction would be to lengthen the validity of the conveyance and examination certificate beyond a mere 24 hours (inserting a provision for the hospital admissions staff to release individuals who are obviously not mentally disordered or dangerous). Then a fair hearing before a judge or administrative body could be required, with medical evidence being presented, within 48 hours (or possibly 72 hours), before involuntary commitment for mental disorder could take place.

It is also possible that the review panel hearing could be found to be an infringement of due process because sessions are conducted in camera, and because the mentally disordered person may be excluded. However, in considering whether similar provisions violated the Canadian Bill of Rights, $R$. v. Gratton ${ }^{80}$ held that in camera hearings did not violate the right to a fair trial, and Re Walsh \& Jordan ${ }^{81}$ decided the same with respect to exclusion of the subject of a hearing where a representative for him was appointed. Nevertheless, the right of an "accused" person to publicly confront his accusers has been a fundamental concept of Anglo-Canadian law since abolition of the Court of the Star Chamber.

It is also possible that there is a right to counsel during the admission process if the Lowry \& Lepper v. $R$. theory of the incorporation of $\mathrm{s} .2$ is correct. The function of counsel at that stage would likely be similar to that set forth in the breathalyzer cases under the federal Bill of Rights. However, such a right would require an overruling of Bachinsky v. Sawyer.

The interpretation of "equality before the law" by the courts, when considering s. 1(b) of the Alberta Bill of Rights, is unlikely to be much, if any, more liberal than that accorded the phrase in construction of the Canadian Bill of Rights. Therefore, it is unlikely that any of the provisions of the Mental Health Act will be held inoperative solely because they deny mentally disordered persons equality before the law.

*o (1973) 17 C.R.N.S. 256 , 5 C.C.C. (2d) 150 (N.B.C.A.).

"1 (1962) 31 D.L.R. (2d) 88, [1962] O.R. 88, 132 C.C.C. 1 (Ont. H.C.). 
The phrase "protection of the law" has hardly been touched in judicial opinions on the federal Bill of Rights. The field therefore seems wide open to a reasonable argument that a certain procedure denies a person protection of the law.

In view of the paucity of judicial interpretation of the Alberta Bill of Rights most of the foregoing has been speculation. However, it has all been based upon the apparently reasonable premise that, in view of the preamble to the Alberta Act and of its wording being nearly identical to that of the Canadian Bill of Rights, decisions on the federal Act are applicable.

\section{CONCLUSION}

A consideration of due process of law in depriving people of their right to liberty must begin with the criteria by which the procedures are set in motion and the people detained. The concepts of "mental disorder" or "insanity" are very fuzzy ones. The definitions in the Mental Health Act and the Criminal Code (and even within the Code, between fitness to stand trial and acquittal on the basis of insanity) are different in both semantics and in substance. That is because each is to be utilized for a distinct purpose.

It has come to be recognized in both criminal and mental health legislation that mental illness, mental disorder, insanity, etc., is not in itself a justification for deprivation of freedom because it is such a value-laden concept. It depends very much upon individual judgment, even amongst psychiatrists. Therefore, there has come to be a second requirement: that the person must also be dangerous. Here the legislation shows considerable variation. In an acquittal on the basis of insanity the individual has usually committed a dangerous act. The requirement in the fitness issue is the considerably weaker one that he has been charged with a criminal offence. The criteria for civil certification, an opinion of the individual's dangerousness to himself or to others, is the most contentious issue of all.

It is the viewpoint of the author that the present criteria for loss of individual liberty on the basis of mental disorder are justifiable ones. However, the reasons for confinement on the basis of unfitness to stand trial, the criteria for civil commitment and even on remand are so close to incarceration merely on the basis of status that great care must be taken to ensure the fairness of the procedures that bring it about.

The preceding pages have brought to light a number of areas where the ordinary criminal and insane criminal is treated more fairly and more justly than someone unfortunate enough to be considered mentally disordered and probably dangerous. A tremendous amount of effort is expended to ensure that a person accused of a criminal offence is not convicted unjustly. Comparatively little attention is paid to the rights of a person involuntarily committed under the Mental Health Act.

Society has elected to leave the issue almost entirely to the discretion of the medical profession. Perhaps this is part of a belief that mental disorder is merely another form of illness. Insofar as the questions of diagnosis and treatment are concerned this delegation of authority seems to have been the best, if not the ideal solution. However, where the issues of individual liberty and coerced treatment arise the results have not been so beneficial.

Lawyers and judges are often accused of being too legalistic and of losing sight of the real issues involved; and there is considerable merit in this criticism. But if the legal profession has been too solicitous of individual liberty on some occasions, the medical profession often does not even 
consider the issue when authorizing involuntary detention for mental disorder. Physicians have a tendency to see the mentally disordered individual as sick and in need of treatment, discarding the person's freedom as relatively unimportant.

Therefore, it is submitted that certain of the legal procedures for involuntary confinement for mental disorder are in need of change. Physicians are anxious that the patient not be "stigmatized" by being dragged through a process similar to that of the criminal justice system. The point has some validity, and a procedure on the elaborate scale of the criminal justice system is unnecessary and probably inappropriate. However, the liberty issue needs to be given greater consideration when coerced commitment is authorized. A hearing before some form of independent tribunal should be required. Indeed, a patient who has had an opportunity to fairly present his case at an impartial hearing is hardly less likely to respond to treatment than one who feels that he has been railroaded into the institution.

The in camera review panel hearings are another area where the rights of the individual have been subordinated to administrative expediency. As well, if the fitness of the accused person to stand trial on the merits of the issue is to fulfil its purpose and be, in practice, more than another means of rounding up misfits, there must be some opportunity for an acquittal on the merits of the accusation.

Due process of law is capable of interpretation on three levels: (1) the narrow English view, as being according to the statutes of Parliament and decisions of the courts, (2) the interpretations of the Canadian Bill of Rights and the Alberta Bill of Rights, and (3) the generally accepted notions of fairness and justice. This article has surveyed statutory provisions for the detention of the mentally disordered in terms of all three formulations, concentrating on the latter two. One conclusion is evident: in too many instances the mentally disordered are deprived of their liberty without due process of law. 